ISSN : 2580-3220, E-ISSN : 2580-4588

J. Mandiri., Vol. 5, No. 2, Desember 2021 (109 - 127)

(C)2017 Lembaga Kajian Demokrasi

dan Pemberdayaan Masyarakat (LKD-PM)

DOI: https://doi.org/10.33753/mandiri.v5i2.173

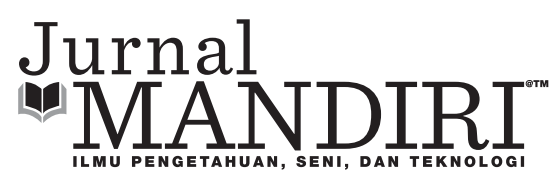

\title{
The Significant Motivation, Communication, and Work Discipline on Employee Performance: Evidence Alfa and Omega Company in South Jakarta
}

\author{
Rob Sosiatri \\ Fakultas Ekonomi dan Bisnis, Universitas Pamulang \\ dosen01136@unpam.ac.id \\ Varindhayani \\ Fakultas Ekonomi dan Bisnis, Universitas Pamulang \\ varindhayani17@gmail.com
}

\begin{abstract}
The purpose of this study was to determine the effect of motivation, communication and work discipline on employee performance at Alfa and Omega Company either partially or simultaneously. The method used is the descriptive method. The sampling technique used is saturated sampling using a sample of 70 respondents. Data analysis used validity test, reliability test, classical assumption test, regression analysis, correlation coefficient analysis, coefficient of determination analysis and hypothesis testing. The results of this study are motivation has a significant effect on employee performance partially. Communication has a significant effect on employee performance partially Work discipline has a significant effect on employee performance partially. Motivation, communication and work discipline simultaneously have a significant effect on employee performance.
\end{abstract}

Keywords : Motivation, Communication, Work Discipline, Employee Performance

\section{INTRODUCTION}

The variable influencing performance is communication. Communication is a process where people, fraction, organization, and society create and use information in order to correlate environment and others. It is implemented by verbal that is understood by both sides.

Building communication creates good teamwork. Communication helps the leaders to coordinate their employments, thus, it makes target of company achieve. The knowledge of that can influence and alter the action to pursuit the objective company. In fact, it is the small things, however, if the communication among employees does not go well it will issue misunderstanding and disturbing the activities of company.

Communication in Alfa and Omega Company does not go well and harmoniously, this is due to the lack of awareness of the leader to convey information related to the work that must be done by the employee. With this, the employees of Alfa and Omega Company experienced a decrease in employee performance. This can be seen from the pre-research table 1 as follows: 
Table 1. Pre-research on communication at Alfa and Omega Company in 2021

The

\section{No. The Question List} Answer

\begin{tabular}{llc} 
& Yes & No \\
\hline 1. & $\begin{array}{l}\text { Does the superiors convey } \\
\text { information clearly? }\end{array}$ & 33 \\
& &
\end{tabular}

2. Are superiors able to show $16 \quad 54$ concern for employees?

Source: Alfa and Omega Company (2021).

Based on the table 1 , it is known that the communication owned by employees and leaders at PT. Alfa And Omega South Jakarta is still not good enough. Based on the observations and observations made by the researchers, the attitude of friendliness and concern for the leadership was mostly answered with the word no by employees who were respondents in the initial survey.

Another variabels that influence the performance is motivation. It is from latin word "movere" which means impetus,propulsion, atau driving force to take actions or do somethings. "Movere" in english is motivation. Someone does something on purpose commonly having a motive or an intention or goal that encourage him to take an action. The Basic motive of someone is a needd that will become a pride and honor. The right motivation can be useful to build awareness of importance of optimal work, discipline and professionalism.

Motivation in Alfa and Omega Company has been issued as well. The reward for employees seems not fair for employees having good job. Then, only half the population of employees' trust obtain. This can be seen from the pre-research table 2 as follows:

Table 2. Pre-research on Motivation at Alfa and Omega Company in 2021

\section{The}

No. The Question List Answer

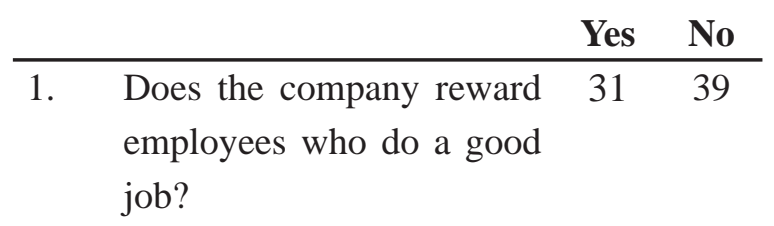

2. Does the superiors always $35 \quad 35$ give trust to employees ?
Table 2 shows the reward and trust for employees. It shows that 31 employees answer yes about the fair reward but 39 employees answer no. It means the unsatisfied employees are biggers than company thinks. Also, 50 percent answer yes about trust whom superiors give, thus, the superior cannot reach all of the employees' motives. It might be a hyphothesis for the declining company performance.

Besides the motivation and communication, work discipline is relevant issue in building good performance. The work discipline is a subject of responsible value. It is conveyed the information by company in order to achieve the satisfied performance. There are several advantages when the employees follow the discipline such as reaching the objective company, employees' satisfaction, and society. The rules are very essential to guide and train the employees until creating the good order, morale employee work efficiency, and effectiveness

In reality, employees' Alfa and Omega are deficient. Our hypothesis is that the leaders do not emphasizes the rules that have been determined. Many employees are not following the existing regulations such as many employees have been late and absence without notification. Furthermore, employees cannot fullfill their due date and it makes the achievement of company not succeed. Following table might be illustrated the employees' attendance Alfa and Omega.

Table 3 illustrates that many employees arrive late, thus giving a bad impact on employee performance. In this case, one of the causes of employees at Alpha and Omega company is a lack of motivation and communication. Lack of motivation and communication causes employees to be undisciplined so that they do not have the enthusiasm to work. Due to poor motivation, communication and work discipline, employee performance at Alfa and Omega company decreased.

As mentioned by (Mangkunegara, 2017:5) employee performance is the evaluation of individual and group work within the company in order to carry out the main tasks that apply within the organization. Employee performance at Alfa

Source: Alfa and Omega Company (2021). 
and Omega company are not good enough due to the lack of enthusiasm of employees in improving their performance, awareness of leaders and employees who are lacking in discipline, creativity, and the difficulty of working with each other. Moreover, communication is often ignored by employees. Therefore the performance of employees at Alfa and Omega company have decreased.

Alfa and Omega company assesses employee performance by comparing the number of performance achievements with performance targets each year. The following is a table of achievement and performance targets at Alfa and Omega Company from 2019 to 2020 as follows.

Table 4 shows that the percentage of overall employee performance achievement in 2019 is $81.5 \%$. In 2020 the percentage of employee performance experienced a decline again, which only reached $72.9 \%$. This shows that employee
(Nurdina, 2018); motivation (Abid \& Safiih, 2021); communication and work discipline (MOGI, 2020); motivation and work satisfied (Oktavianti, 2020); organizational culture and motivation (Mulyadi \& Wicaksono, 2019); gender (Asadullah et al., 2021); emotional intelligence (Jie et al., 2020); leadership, communication and motivation (Khair, 2018); supervision and work discipline (Tohirin, 2018); motivation and work discipline (Astria, 2018); work discipline (Krisnaldy et al., 2020); training and work discipline (Nazir, 2019); work motivation, commitment, and discipline (Santoso, 2017); job rotation, organizational communication and work satisfaction (Senen, 2021); employment perrformance manegement reduce the quality life (Audenaert et al., 2021). From those phenomena and previous literature we are interested in the effect of motivation, communication and work discipline on employee performance at Alfa and Omega company in South Jakarta partially and simultaneously.

Table 3. Work discipline data (attendance) Alfa And Omega Company in South Jakarta from 2019 to 2020

\begin{tabular}{cccccc}
\hline Time & $\begin{array}{c}\text { Employees' } \\
\text { Number }\end{array}$ & Sick & The Reason of Absence & Overdue \\
& 70 & 16 & 20 & 10 & \\
\hline 2019 & 70 & 13 & 18 & 20 & 73 \\
2020 & & 29 & 38 & 30 & 64 \\
\hline TOTAL & & & & & \\
\hline
\end{tabular}

Source: Alfa and Omega Company (2021).

Table 4. Performance Alfa and Omega Company in South Jakarta from 2019 to 2020

\begin{tabular}{cccc}
\hline Time & Achievements & Targets & Percentages \\
\hline 2019 & Rp 32.600.000.000,00 & Rp 40.000.000.000,00 & 81.5 \\
2020 & Rp 30.600.000.000,00 & Rp 42.000.000.000,00 & 72.9 \\
\hline
\end{tabular}

Source: Alfa and Omega Company (2021).

performance is low, because it does not reach the desired target of the company. The data has limited in a year not a month.

Several literature has been made previously, such as The significant motivation, communcation and work stress on teacher performance(Cay, 2018); communication and training clinic performance (Susanti, 2019); communication (Barsah, 2019); ethical work and disciplined work(Barsah \& Ridwan, 2020); work discipline and work situation (Handayani, 2020); work stress and work discipline (Rahmi, 2020); compensation and work discipline (Pratama, 2020); organizational culture and work motivation

\section{METHODS}

This research uses Alfa and Omega company as the place of research. The population and sample of research are 70 people. The time of data are 2 years from 2019 to 2020 . The data used are primary data that are collected by questionnaire.The secondary data are employee data such as absence and literature review. The model used is multiple regression that must be examined by BLUE estimator. BLUE estimators used are linierity, normality, multicolinearity, autocorrelation and heteroskedasticity.

Table 5 shows the indicators every variables, 
Table 5. The operational variables research

\begin{tabular}{|c|c|c|c|}
\hline Variables & Indicators & Question Numbers Kuesioner & Scalas \\
\hline \multirow{5}{*}{$\begin{array}{c}\text { Motivation (X1) } \\
\text { (Suwatno \& Priansa, } \\
\text { 2016:177) }\end{array}$} & 1.Physiological needs & $1,2,3,4$ & Likert \\
\hline & 2.Safety needs & $5,6,7,8$ & \\
\hline & 3.Social needs & $9,10,11$ & \\
\hline & 4.Appreciation needs & $12,13,14$ & \\
\hline & 5.Self-actualization & & \\
\hline \multirow{4}{*}{$\begin{array}{l}\text { Communication } \\
\text { (X2) (Sutardji, } \\
\text { 2016:10-11) }\end{array}$} & 1.Understanding & $1,2,3,4$ & Likert \\
\hline & 2.Pleasure & $5,6,7,8$ & \\
\hline & 3.Influence on attitude & $9,10,11$ & \\
\hline & 4.Improved & $12,13,14$ & \\
\hline \multirow{7}{*}{$\begin{array}{c}\text { Work Discipline } \\
\text { (X3) (Hasibuan, } \\
\text { 2017:194) }\end{array}$} & 1.Aims and Abilities & 1,2 & Likert \\
\hline & 2.Exemplary Leaders & 3,4 & \\
\hline & 3.Repayment & 5,6 & \\
\hline & 4.Justice & 7,8 & \\
\hline & 5.Waskat & 9,10 & \\
\hline & 6.Punishment & 11,12 & \\
\hline & 7.Firmness & 13,14 & \\
\hline \multirow{5}{*}{$\begin{array}{l}\text { Employees' Perfor- } \\
\text { mance (Y) (Mang- } \\
\text { kunegara, 2017:75) }\end{array}$} & 1.Quality of Work & $1,2,3,4$ & Likert \\
\hline & 2.Quantity of Work & $5,6,7,8$ & \\
\hline & 3.Implementation of $\mathrm{Du}-$ & & \\
\hline & ties & $9,10,11,12$ & \\
\hline & 4.Responsibilities & & \\
\hline
\end{tabular}

the question number and the scalas. The motivation variable has five indicators such as physiological, safety, social, appreciation, and self-actualization needs. The communication variable has five indicators that are understanding, pleasure, influence on attitude, improved relationship, and actions. Work discipline variable has eight indicators that are aims and abilities, exemplary leaders, repayment, justice, waskat, punishment, firmness, and human relations. The last variable is employees' performance. It has four indicators such as quality of work, quantity of work, implementation of duties and responsibilities. Every indicators has statement to measure the variables with scalas likert.

Table 6 shows the indicators statements of motivation. The physiological needs' statements are from 1 to 4 . The safety needs' statements are from 5 to 8 . The social needs' statements are from 9 to 11. The appreciation needs' statements are from 12 to 14 . The self-actualization needs' statements are 15 and 16 .

Table 7 shows the statements of communication indicators. Understanding's statements are from 1 to 4 . Pleasure's statements are from 5 to 8 . Influence on attitude's statements are from 9 to 11 . The improved relationship's statements are from 12 to 14 . The actions' statements are 15 and 16 .

Table 8 shows the statements' work discipline indicators. The aim and abilities' statements are 1 and 2. The exemplary leaders' statements are 3 and 4 . The repayment's statements are 5 and 6. Justice's statements are 7 and 8 . The waskat's statements are 9 and 10. The punishment's statements are 11 and 12 . The firmness' statements are 13 and 14. The human relatioans' statements are 15 and 16 .

Table 10 shows likerts categories. Categories 
Table 6. The statements of motivation variable

\begin{tabular}{|c|c|c|}
\hline No. & Indicators of Motivation & Statements \\
\hline 1. & & The company salary is in accordance with applicable regulations \\
\hline 2. & & $\begin{array}{l}\text { The company provides incentives in accordance with applicable } \\
\text { policies }\end{array}$ \\
\hline 3. & Physiological needs & $\begin{array}{l}\text { The salary and incentives provided by the company to employees } \\
\text { make employees motivated to work }\end{array}$ \\
\hline 4. & & $\begin{array}{l}\text { Employees are satisfied with the incentives provided by the com- } \\
\text { pany }\end{array}$ \\
\hline 5. & & The safety in the work environment is well managed \\
\hline 6. & & Workspace facilities that are used are comfortable and clean \\
\hline 7. & Safety needs & Labor social security is given evenly to all employees \\
\hline 8. & & $\begin{array}{l}\text { Work safety equipment is considered very good to protect em- } \\
\text { ployees }\end{array}$ \\
\hline 9. & Social needs & Working relationship with superiors or leaders is well established \\
\hline 10. & & $\begin{array}{l}\text { The working relationship among co-workers in this company is } \\
\text { harmonious }\end{array}$ \\
\hline 11. & & $\begin{array}{l}\text { The company rewards employees who do a good job (achieve- } \\
\text { ment) }\end{array}$ \\
\hline 12. & & The company promotes outstanding employees \\
\hline 13. & Appreciation needs & $\begin{array}{l}\text { So far, the company recognizes and appreciates the hard work of } \\
\text { employees }\end{array}$ \\
\hline 14. & & $\begin{array}{l}\text { The award given is in accordance with the hard work of the work- } \\
\text { ers }\end{array}$ \\
\hline 15. & & $\begin{array}{l}\text { The motivation given by my boss makes me more disciplined at } \\
\text { work }\end{array}$ \\
\hline 16. & Self-actualization needs & $\begin{array}{l}\text { The company has provided education and training to increase em- } \\
\text { ployee potential }\end{array}$ \\
\hline
\end{tabular}

Source: (Suwatno \& Priansa, 2016). 
Table 7. The statements of communication variable

\begin{tabular}{|c|c|c|}
\hline No. & Indicators of Motivation & Statements \\
\hline 1. & & The information conveyed by superiors is clear \\
\hline 2. & Understanding & $\begin{array}{l}\text { Employees understand the tasks and information submitted by } \\
\text { superiors }\end{array}$ \\
\hline 3. & & There is a good interaction between management and employees \\
\hline 4. & & Employees receive and carry out the results of the joint meeting \\
\hline 5. & & $\begin{array}{l}\text { Communication takes place comfortably and feels positive emo- } \\
\text { tions as a result of communicating with superiors }\end{array}$ \\
\hline 6. & & Employees are understood by superiors \\
\hline 7. & Pleasure & $\begin{array}{l}\text { Flexible and pleasant communication makes employees enthusi- } \\
\text { astic in carrying out orders from superiors }\end{array}$ \\
\hline 8. & & $\begin{array}{l}\text { Employees often participate in conversations about problems in } \\
\text { the office }\end{array}$ \\
\hline 9. & & Poor communication makes employees lazy to work \\
\hline 10. & Influence on attitude & $\begin{array}{l}\text { Employees will carry out the tasks assigned by their superiors if } \\
\text { the information conveyed is clear }\end{array}$ \\
\hline 11. & & $\begin{array}{l}\text { Employees feel afraid when communicating with leaders who } \\
\text { tend to ignore suggestions and input from others }\end{array}$ \\
\hline 12. & & $\begin{array}{l}\text { With good communication between leaders and employees, it will } \\
\text { create a good working environment }\end{array}$ \\
\hline 13. & Improved relationship & Good communication will improve employee coordination \\
\hline 14. & & Employees have a good relationship with the staff in the company \\
\hline 15. & Actions & Employee sales will increase if communication goes well \\
\hline 16. & & $\begin{array}{l}\text { Employees always give their best for the company's customer ser- } \\
\text { vice }\end{array}$ \\
\hline
\end{tabular}

Source : (Sutardji, 2016).

Table 8. The statements of work discipline variable

\begin{tabular}{|c|c|c|}
\hline No. & Indicators of Motivation & Statements \\
\hline 1. & & Employees know the goals that employees will achieve \\
\hline 2. & Aims and abilities & $\begin{array}{l}\text { The work given by the boss is in accordance with the employee's } \\
\text { abilities }\end{array}$ \\
\hline 3. & & Employee leaders are good leaders honest and fair \\
\hline 4. & Exemplary leaders & Leaders have set a good example \\
\hline 5. & & Basic salary paid punctually on time as expected \\
\hline 6. & Repayment & There is a chance to get promoted \\
\hline 7. & & Receive rewards when employees achieve targets \\
\hline 8. & Justice & Get punished if the employee does not reach the target \\
\hline 9. & Waskat & $\begin{array}{l}\text { Leaders monitor the behavior, morals, attitudes and work perfor- } \\
\text { mance of their subordinates }\end{array}$ \\
\hline 10. & & Leaders help employees when employees have difficulties \\
\hline 11. & & Punish employees for arriving late \\
\hline 12. & Punishment & $\begin{array}{l}\text { The punishment given is heavy so that employees don't want to } \\
\text { violate it again }\end{array}$ \\
\hline
\end{tabular}


13.

14. Firmness

15.

16.
Punish employees in accordance with the sanctions that have been set

Give a warning when breaking the rules

Leaders create good relationships with employees

Leaders establish good relations with employees without exception so that they can motivate employees to comply with existing regulations

Source : (Sutardji, 2016).

Table 9. The statements of employees' performance variable

\begin{tabular}{|c|c|c|}
\hline No. & Indicators of Motivation & Statements \\
\hline 1. & & $\begin{array}{l}\text { With the knowledge that employees have, employees can mas- } \\
\text { ter the fields and tasks that employees do with good results }\end{array}$ \\
\hline 2. & Quality of work & Employees do a job carefully and thoroughly \\
\hline 3. & & $\begin{array}{l}\text { The company encourages employees to produce optimal qual- } \\
\text { ity of work }\end{array}$ \\
\hline 4. & & $\begin{array}{l}\text { Employees are able to complete tasks in accordance with the } \\
\text { instructions of superiors }\end{array}$ \\
\hline 5. & & $\begin{array}{l}\text { The level of achievement of the volume of work that employ- } \\
\text { ees produce is in accordance with company expectations }\end{array}$ \\
\hline 6. & Quantity of work & $\begin{array}{l}\text { The quantity of work provided is in accordance with the com- } \\
\text { pany's expectations }\end{array}$ \\
\hline 7. & & $\begin{array}{l}\text { Employees can work according to the targets set by the com- } \\
\text { pany }\end{array}$ \\
\hline 8. & & $\begin{array}{l}\text { Employees are able to complete work targets good and punc- } \\
\text { tual }\end{array}$ \\
\hline 9. & & Employees perform tasks accurately and without errors \\
\hline 10. & Implementation of Duties & $\begin{array}{l}\text { Employees carry out tasks in accordance with the job descrip- } \\
\text { tion }\end{array}$ \\
\hline 11. & & Employees always minimize mistakes at work \\
\hline 12. & & Employees always try to do their best \\
\hline 13. & Responsibilities & Employees do their job with full responsibility \\
\hline 14. & & All forms of work errors are the responsibility of the employee \\
\hline 15. & & Employees try their best to complete the assigned tasks \\
\hline 16. & & Employees are responsible for the work given to completion \\
\hline
\end{tabular}

Source: (Mangkunegara, 2017).

Table 10. The statements of employees' performance variable

\begin{tabular}{cc}
\hline Score & Categories \\
\hline 5 & Strongly Agree/Very Good \\
4 & Agree/Ok \\
3 & Doubtful/Good Enough \\
2 & Less Agree/Poor \\
1 & Disagree/Bad \\
\hline
\end{tabular}

Source: Sugiyono (2018:94). 
$5,4,3,2$, and 1 are either very good, ok, good enough, poor, and bad or strongly agree, agree, doubtful, less agree, and disagree.

\section{RESULTS}

The Following table shows the population and sample employees' Alfa and Omega . the data is collected from Alfa and Omega company.
Table 11 shows the population and sample all employees. Population and sample are equal because this research data are below 100 .

Table 12 shows the results presented in the table above. It shows that employees who work $>5$ years are $81.4 \%$ and employees who work over 6-10 years are $18.6 \%$.

Table 13 shows that motivation variable

Table 11. Employees' position on Alfa and Omega Company

\begin{tabular}{lcc}
\hline \multicolumn{1}{c}{ Position } & Population & Sample \\
\hline General Manager & 1 & 1 \\
Financial Manager & 1 & 1 \\
Marketing Manager & 1 & 1 \\
Marketing & 5 & 5 \\
Accounting & 1 & 1 \\
Admin Intern & 1 & 1 \\
Admin Support & 1 & 1 \\
Customer Service & 1 & 1 \\
Operation & 1 & 1 \\
Technician & 28 & 28 \\
Helper & 28 & 28 \\
Cleaning Service & 1 & 1 \\
\hline
\end{tabular}

Source: Alfa and Omega Company (2021).

Table 12. Respondent data based on duration work

\begin{tabular}{|c|c|c|c|}
\hline No. & Duration Work & Frequencies & Percentages \\
\hline 1 & $<5$ years & 57 & 81,4 \\
\hline 2 & $6-10$ years & 13 & 18,6 \\
\hline \multicolumn{2}{|c|}{ Total } & 70 & 100 \\
\hline
\end{tabular}

Source: Alfa and Omega (2021): primary data.

Table 13. The respondent answer based on motivation variable (X1)

\begin{tabular}{|c|c|c|c|c|c|c|c|c|c|}
\hline \multirow[b]{2}{*}{ No. } & \multicolumn{9}{|c|}{ The Answer Criterions } \\
\hline & Statements & $\begin{array}{c}\text { SA } \\
\mathbf{5}\end{array}$ & $\begin{array}{l}\text { A } \\
4\end{array}$ & $\begin{array}{l}\text { D } \\
3\end{array}$ & $\begin{array}{c}\text { LS } \\
2\end{array}$ & $\begin{array}{c}\text { DA } \\
1\end{array}$ & Total & $\begin{array}{c}\text { Em- } \\
\text { ployee's } \\
\text { Number }\end{array}$ & $\begin{array}{l}\text { Mean } \\
\text { Scores }\end{array}$ \\
\hline 1 & $\begin{array}{l}\text { The company salary is in } \\
\text { accordance with applicable } \\
\text { regulations }\end{array}$ & 9 & 21 & 35 & 5 & 0 & 244 & 70 & 3.49 \\
\hline 2 & $\begin{array}{l}\text { The company provides in- } \\
\text { centives in accordance with } \\
\text { applicable policies }\end{array}$ & 12 & 4 & 49 & 5 & 0 & 233 & 70 & 3.33 \\
\hline 3 & $\begin{array}{l}\text { The salary and incentives } \\
\text { provided by the company } \\
\text { to employees make em- } \\
\text { ployees motivated to work }\end{array}$ & 12 & 9 & 48 & 1 & 0 & 242 & 70 & 3.46 \\
\hline
\end{tabular}




\begin{tabular}{|c|c|c|c|c|c|c|c|c|c|}
\hline 4 & $\begin{array}{l}\text { Employees are satisfied } \\
\text { with the incentives provid- } \\
\text { ed by the company }\end{array}$ & 10 & 26 & 28 & 6 & 0 & 250 & 70 & 3.57 \\
\hline 5 & $\begin{array}{l}\text { The safety in the work en- } \\
\text { vironment is well managed }\end{array}$ & 5 & 20 & 34 & 1 & 0 & 249 & 70 & 3.56 \\
\hline 6 & $\begin{array}{l}\text { Workspace facilities that } \\
\text { are used are comfortable } \\
\text { and clean }\end{array}$ & 11 & 26 & 29 & 4 & 0 & 254 & 70 & 3.63 \\
\hline 7 & $\begin{array}{l}\text { Labor social security is giv- } \\
\text { en evenly to all employees }\end{array}$ & 12 & 17 & 38 & 3 & 0 & 248 & 70 & 3.54 \\
\hline 8 & $\begin{array}{l}\text { Work safety equipment is } \\
\text { considered very good to } \\
\text { protect employees }\end{array}$ & 20 & 28 & 22 & 0 & 0 & 278 & 70 & 3.97 \\
\hline 9 & $\begin{array}{l}\text { Working relationship with } \\
\text { superiors or leaders is well } \\
\text { established }\end{array}$ & 11 & 16 & 29 & 4 & 0 & 254 & 70 & 3.63 \\
\hline 10 & $\begin{array}{l}\text { The working relationship } \\
\text { among co-workers in this } \\
\text { company is harmonious }\end{array}$ & 12 & 6 & 42 & 10 & 0 & 230 & 70 & 3.29 \\
\hline 11 & $\begin{array}{l}\text { The company rewards em- } \\
\text { ployees who do a good job } \\
\text { (achievement) }\end{array}$ & 7 & 40 & 15 & 8 & 0 & 256 & 70 & 3.66 \\
\hline 12 & $\begin{array}{l}\text { The company promotes } \\
\text { outstanding employees }\end{array}$ & 29 & 21 & 13 & 7 & 0 & 282 & 70 & 4.03 \\
\hline 13 & $\begin{array}{l}\text { So far, the company recog- } \\
\text { nizes and appreciates the } \\
\text { hard work of employees }\end{array}$ & 12 & 36 & 17 & 5 & 0 & 265 & 70 & 3.79 \\
\hline 14 & $\begin{array}{l}\text { The award given is in ac- } \\
\text { cordance with the hard } \\
\text { work of the workers }\end{array}$ & 12 & 27 & 24 & 7 & 0 & 254 & 70 & 3.63 \\
\hline 15 & $\begin{array}{l}\text { The motivation given by } \\
\text { my boss makes me more } \\
\text { disciplined at work }\end{array}$ & 10 & 23 & 36 & 1 & 0 & 252 & 70 & 3.60 \\
\hline \multirow[t]{3}{*}{16} & $\begin{array}{l}\text { The company has provided } \\
\text { education and training to } \\
\text { increase employee poten- } \\
\text { tial }\end{array}$ & 5 & 46 & 13 & 6 & 0 & 260 & 70 & 3.71 \\
\hline & Total & 189 & 386 & 472 & 73 & 0 & 4051 & 1120 & Average \\
\hline & Percentage & 16.9 & 34.5 & 42.1 & 6.5 & 0.0 & 100 & Average & 3.62 \\
\hline
\end{tabular}

Source: Self-processed primary data. 
average is in 3.62. The Lowest average is number 10 about the working relationship among coworkers in this company is harmonious with 3.29. Thus, the highest is number 12 that the company promotes outstanding employees with 4.03.

Table 14 shows the average of communication variable is 3.81 . The lowest average is number 11 that employees feel afraid when communicating with leaders who tend to ignore suggestions and input from others with 3.57. The highest average is number 14 that employees have a good relationship with the staff in the company with 4.19 .

Table 15 shows the average of work discipline

Table 14. Respondent data based on communication variable (X2)

\begin{tabular}{|c|c|c|c|c|c|c|c|c|c|}
\hline \multirow[b]{2}{*}{ No. } & \multicolumn{9}{|c|}{ The Answer Criterions } \\
\hline & Statements & $\begin{array}{c}\text { SA } \\
5\end{array}$ & $\begin{array}{c}\mathrm{A} \\
\mathbf{4}\end{array}$ & $\begin{array}{l}\text { D } \\
\mathbf{3}\end{array}$ & $\begin{array}{c}\mathbf{L S} \\
2\end{array}$ & $\begin{array}{c}\text { DA } \\
\mathbf{1}\end{array}$ & Total & $\begin{array}{c}\text { Em- } \\
\text { ployee's } \\
\text { Number }\end{array}$ & $\begin{array}{l}\text { Mean } \\
\text { Scores }\end{array}$ \\
\hline 1 & $\begin{array}{l}\text { The information conveyed } \\
\text { by superiors is clear }\end{array}$ & 19 & 29 & 17 & 4 & 1 & 271 & 70 & 3.87 \\
\hline 2 & $\begin{array}{l}\text { Employees understand the } \\
\text { tasks and information sub- } \\
\text { mitted by superiors }\end{array}$ & 15 & 33 & 17 & 4 & 1 & 267 & 70 & 3.81 \\
\hline 3 & $\begin{array}{l}\text { There is a good interaction } \\
\text { between management and } \\
\text { employees }\end{array}$ & 9 & 36 & 22 & 3 & 0 & 261 & 70 & 3.73 \\
\hline 4 & $\begin{array}{l}\text { Employees receive and } \\
\text { carry out the results of the } \\
\text { joint meeting }\end{array}$ & 13 & 26 & 25 & 6 & 0 & 256 & 70 & 3.66 \\
\hline 5 & $\begin{array}{l}\text { Communication takes } \\
\text { place comfortably and } \\
\text { feels positive emotions as } \\
\text { a result of communicating } \\
\text { with superiors }\end{array}$ & 9 & 33 & 23 & 6 & 0 & 253 & 70 & 3.61 \\
\hline 6 & $\begin{array}{l}\text { Employees are understood } \\
\text { by superiors }\end{array}$ & 10 & 32 & 21 & 7 & 0 & 255 & 70 & 3.64 \\
\hline 7 & $\begin{array}{l}\text { Flexible and pleasant } \\
\text { communication makes } \\
\text { employees enthusiastic in } \\
\text { carrying out orders from } \\
\text { superiors }\end{array}$ & 13 & 30 & 22 & 5 & 0 & 261 & 70 & 3.73 \\
\hline 8 & $\begin{array}{l}\text { Employees often par- } \\
\text { ticipate in conversations } \\
\text { about problems in the of- } \\
\text { fice }\end{array}$ & 11 & 31 & 25 & 3 & 0 & 260 & 70 & 3.71 \\
\hline 9 & $\begin{array}{l}\text { Poor communication } \\
\text { makes employees lazy to } \\
\text { work }\end{array}$ & 18 & 29 & 20 & 3 & 0 & 272 & 70 & 3.89 \\
\hline
\end{tabular}


10 Employees will carry out the tasks assigned by their superiors if the information conveyed is clear

11 Employees feel afraid when communicating with leaders who tend to ignore suggestions and input from others

12 With good communication between leaders and employees, it will create a good working environment

13 Good communication will improve employee coordination

14 Employees have a good relationship with the staff in the company

15 Employee sales will increase if communication 20 2

13

14

0

259

70 goes well

16 Employees always give their best for the company's customer service

\begin{tabular}{lcccccccc}
\hline Total & 244 & 490 & 318 & 64 & 4 & 4266 & 1120 & Average \\
\hline Percentages & 21.8 & 43.8 & 28.4 & 5.7 & 0.4 & 100 & Average & 3.81 \\
\hline
\end{tabular}

Source: Self-processed primary data. 
Table 15. Respondent data based on work discipline variable (X3)

\section{The Answer Criterions}

\begin{tabular}{|c|c|c|c|c|c|c|c|c|c|}
\hline No. & Statements & $\begin{array}{c}\text { SA } \\
5\end{array}$ & $\begin{array}{l}\text { A } \\
4\end{array}$ & $\begin{array}{l}\mathbf{D} \\
\mathbf{3}\end{array}$ & $\begin{array}{c}\text { LS } \\
2\end{array}$ & $\begin{array}{c}\text { DA } \\
\mathbf{1}\end{array}$ & Total & $\begin{array}{l}\text { ployee's } \\
\text { Num- } \\
\text { ber }\end{array}$ & $\begin{array}{l}\text { Mean } \\
\text { Scores }\end{array}$ \\
\hline 1 & $\begin{array}{l}\text { Employees know the goals } \\
\text { that employees will achieve }\end{array}$ & 21 & 5 & 40 & 4 & 0 & 253 & 70 & 3.61 \\
\hline 2 & $\begin{array}{l}\text { The work given by the boss } \\
\text { is in accordance with the } \\
\text { employee's abilities }\end{array}$ & 16 & 31 & 20 & 3 & 0 & 270 & 70 & 3.86 \\
\hline 3 & $\begin{array}{l}\text { Employee leaders are good } \\
\text { leaders honest and fair }\end{array}$ & 19 & 29 & 15 & 5 & 2 & 268 & 70 & 3.83 \\
\hline 4 & $\begin{array}{l}\text { Leaders have set a good } \\
\text { example }\end{array}$ & 16 & 28 & 20 & 5 & 1 & 263 & 70 & 3.76 \\
\hline 5 & $\begin{array}{l}\text { Basic salary paid punctu- } \\
\text { ally on time as expected }\end{array}$ & 22 & 32 & 13 & 3 & 0 & 283 & 70 & 4.04 \\
\hline 6 & $\begin{array}{l}\text { There is a chance to get } \\
\text { promoted }\end{array}$ & 17 & 32 & 17 & 3 & 1 & 271 & 70 & 3.87 \\
\hline 7 & $\begin{array}{l}\text { Receive rewards when } \\
\text { employees achieve targets }\end{array}$ & 16 & 29 & 18 & 5 & 2 & 262 & 70 & 3.74 \\
\hline 8 & $\begin{array}{l}\text { Get punished if the em- } \\
\text { ployee does not reach the } \\
\text { target }\end{array}$ & 17 & 31 & 18 & 3 & 1 & 270 & 70 & 3.86 \\
\hline 9 & $\begin{array}{l}\text { Leaders monitor the be- } \\
\text { havior, morals, attitudes } \\
\text { and work performance of } \\
\text { their subordinates }\end{array}$ & 15 & 36 & 13 & 4 & 2 & 268 & 70 & 3.83 \\
\hline 10 & $\begin{array}{l}\text { Leaders help employees } \\
\text { when employees have dif- } \\
\text { ficulties }\end{array}$ & 13 & 32 & 17 & 7 & 1 & 259 & 70 & 3.70 \\
\hline 11 & $\begin{array}{l}\text { Punish employees for ar- } \\
\text { riving late }\end{array}$ & 33 & 22 & 8 & 7 & 0 & 291 & 70 & 4.16 \\
\hline 12 & $\begin{array}{l}\text { The punishment given is } \\
\text { heavy so that employees } \\
\text { don't want to violate it } \\
\text { again }\end{array}$ & 31 & 29 & 10 & 0 & 0 & 301 & 70 & 4.30 \\
\hline 13 & $\begin{array}{l}\text { Punish employees in ac- } \\
\text { cordance with the sanc- } \\
\text { tions that have been set }\end{array}$ & 20 & 32 & 17 & 1 & 0 & 281 & 70 & 4.01 \\
\hline 14 & $\begin{array}{l}\text { Give a warning when } \\
\text { breaking the rules }\end{array}$ & 15 & 12 & 36 & 7 & 0 & 245 & 70 & 3.50 \\
\hline 15 & $\begin{array}{l}\text { Leaders create good rela- } \\
\text { tionships with employees }\end{array}$ & 31 & 27 & 11 & 1 & 0 & 298 & 70 & 4.26 \\
\hline
\end{tabular}




\begin{tabular}{l}
$16 \begin{array}{l}\text { Leaders establish good } \\
\begin{array}{l}\text { relations with employees } \\
\text { without exception so that }\end{array} \\
\text { they can motivate employ- } \\
\text { ees to comply with existing } \\
\text { regulations }\end{array}$ \\
\hline
\end{tabular}

Source: Self-processed primary data.

is 3.88. The lowest average is number 14 that give a warning when breaking the rules with 3.50 . The highest average is number 15 that leaders create good relationships with employees with 4.26.

Table 16 shows that the average of employee performance is 3.68. The lowest average is number 2 that employees do a job carefully and thoroughly with 3.34 . The highest average is number 8 that employees are able to complete work targets well and on time with 4.24.

Table 17 explains that the regression equation $\mathrm{Y}=28.490+0.581 \mathrm{X} 1 \mathrm{can}$ be obtained. From the above equation, The constant value of 28.490 means that if the motivation variable (X1) does not exist, then there is an employee performance value (Y) of 28.490 points. The value of the motivation regression coefficient (X1) of 0.581 means that if the constant is constant and there is no change in communication (X2) and work discipline (X3), then every 1 unit change in the motivation variable (X1) will result in a change in employee performance (Y) of 0.581 points.

Table 18 shows that the regression equation $\mathrm{Y}$ $=27.148+0.574 \mathrm{X} 2$ can be obtained. From the above equation, The constant value of 27.148 means that if there is no communication (X2), then there has been an employee performance value (Y) of 27.148 points. The value of the communication regression coefficient (X2) of 0.574 means that if the constant is fixed and there is no change in the motivation variable (X1) and work discipline (X3) then every 1 unit change in the communication variable (X2) will result in a change in employee performance ( $\mathrm{Y}$ ) of 0.574 points.

Based on the results of the regression calculations in the table above, the regression equation $\mathrm{Y}=22.162+0.679 \mathrm{X} 3$ can be obtained. From the above equation, The constant value of 22.162 means that if there is no work discipline (X3), then there is already an employee performance value (Y) of 22,162 points. The value of the work discipline regression coefficient (X3) of 0.679 means that if the constant is fixed and there is no change in the motivation variable (X1) and communication (X2) then every 1 unit change in the work discipline variable (X3) will result in a change in employee performance. (Y) of 0.679 points.

Based on the results of the analysis of the regression calculations in the table above, it can be obtained the regression equation $\mathrm{Y}=-1.172$ $+0.169 \mathrm{X} 1+0.462 \mathrm{X} 2 .+0.432 \mathrm{X} 3$. The constant value of -1.172 means that if the motivation (X1), communication (x2) and work discipline (X3) variables do not exist, then there is an employee performance value (Y) of -1.172 points. The value of motivation (X1) 0.169 means that if the constant is fixed and there is no change in the communication variable (X2) and work discipline (X3), then every 1 unit change in the motivation variable (X1) will result in a change in employee performance ( $\mathrm{Y}$ ) of 1,172 points. The communication value (X2) 0.462 means that if the constant is fixed and there is no change in the motivation variable (X1) and work discipline (X3), then every 1 unit change in the communication variable $(\mathrm{X} 2)$ will result in a change in employee performance (Y) of 0.462 points. The value of work discipline (X3) 0.432 means that if the constant is fixed and there is no change in the motivation variable (X1) and communication (X2), then every 1 unit change in the work discipline variable (X3) will result in a change in employee performance $(\mathrm{Y})$ of 0.432 points. 
Table 16. Respondent data based on employees performance (Y)

\begin{tabular}{|c|c|c|c|c|c|c|c|c|c|}
\hline \multirow[b]{2}{*}{ No. } & \multicolumn{9}{|c|}{ The Answer Criterions } \\
\hline & Statements & $\begin{array}{c}\text { SA } \\
5\end{array}$ & $\begin{array}{l}\mathrm{A} \\
4\end{array}$ & $\begin{array}{l}\mathbf{D} \\
\mathbf{3}\end{array}$ & $\begin{array}{c}\text { LS } \\
2\end{array}$ & $\begin{array}{c}\text { DA } \\
\mathbf{1}\end{array}$ & Total & $\begin{array}{c}\text { Em- } \\
\text { ployee's } \\
\text { Number }\end{array}$ & $\begin{array}{l}\text { Mean } \\
\text { Scores }\end{array}$ \\
\hline 1 & $\begin{array}{l}\text { With the knowledge that } \\
\text { employees have, employ- } \\
\text { ees can master the fields } \\
\text { and tasks that employees } \\
\text { do with good results }\end{array}$ & 13 & 39 & 15 & 3 & 0 & 272 & 70 & 3.89 \\
\hline 2 & $\begin{array}{l}\text { Employees do a job care- } \\
\text { fully and thoroughly }\end{array}$ & 13 & 3 & 49 & 5 & 0 & 234 & 70 & 3.34 \\
\hline 3 & $\begin{array}{l}\text { The company encourages } \\
\text { employees to produce opti- } \\
\text { mal quality of work }\end{array}$ & 8 & 29 & 19 & 14 & 0 & 241 & 70 & 3.44 \\
\hline 4 & $\begin{array}{l}\text { Employees are able to } \\
\text { complete tasks in accor- } \\
\text { dance with the instruc- } \\
\text { tions of superiors }\end{array}$ & 10 & 24 & 30 & 6 & 0 & 248 & 70 & 3.54 \\
\hline 5 & $\begin{array}{l}\text { The level of achievement } \\
\text { of the volume of work that } \\
\text { employees produce is in } \\
\text { accordance with company } \\
\text { expectations }\end{array}$ & 5 & 31 & 33 & 1 & 0 & 250 & 70 & 3.57 \\
\hline 6 & $\begin{array}{l}\text { The quantity of work pro- } \\
\text { vided is in accordance } \\
\text { with the company's expec- } \\
\text { tations }\end{array}$ & 9 & 26 & 31 & 4 & 0 & 250 & 70 & 3.57 \\
\hline 7 & $\begin{array}{l}\text { Employees can work ac- } \\
\text { cording to the targets set } \\
\text { by the company }\end{array}$ & 10 & 37 & 12 & 11 & 0 & 256 & 70 & 3.66 \\
\hline 8 & $\begin{array}{l}\text { Employees are able to } \\
\text { complete work targets } \\
\text { good and punctual }\end{array}$ & 34 & 22 & 11 & 3 & 0 & 297 & 70 & 4.24 \\
\hline 9 & $\begin{array}{l}\text { Employees perform tasks } \\
\text { accurately and without er- } \\
\text { rors }\end{array}$ & 14 & 33 & 18 & 5 & 0 & 266 & 70 & 3.80 \\
\hline 10 & $\begin{array}{l}\text { Employees carry out tasks } \\
\text { in accordance with the job } \\
\text { description }\end{array}$ & 10 & 21 & 37 & 2 & 0 & 249 & 70 & 3.56 \\
\hline 11 & $\begin{array}{l}\text { Employees always mini- } \\
\text { mize mistakes at work }\end{array}$ & 7 & 34 & 26 & 3 & 0 & 255 & 70 & 3.64 \\
\hline 12 & $\begin{array}{l}\text { Employees always try to } \\
\text { do their best }\end{array}$ & 19 & 9 & 40 & 2 & 0 & 255 & 70 & 3.64 \\
\hline
\end{tabular}




\begin{tabular}{|c|c|c|c|c|c|c|c|c|}
\hline $\begin{array}{l}13 \text { Employees do their job } \\
\text { with full responsibility }\end{array}$ & 29 & 27 & 14 & 0 & 0 & 295 & 70 & 4.21 \\
\hline $\begin{array}{l}\text { All forms of work errors } \\
\text { are the responsibility of } \\
\text { the employee }\end{array}$ & 10 & 19 & 32 & 9 & 0 & 240 & 70 & 3.43 \\
\hline $\begin{array}{l}\text { Employees try their best } \\
\text { to complete the assigned } \\
\text { tasks }\end{array}$ & 17 & 20 & 21 & 12 & 0 & 252 & 70 & 3.60 \\
\hline $\begin{array}{l}\text { Employees are responsi- } \\
\text { ble for the work given to } \\
\text { completion }\end{array}$ & 24 & 15 & 19 & 12 & 0 & 261 & 70 & 3.73 \\
\hline Total & 232 & 389 & 407 & 92 & 0 & 4121 & 1120 & Rata2 \\
\hline Percentages & 20.7 & 34.7 & 36.3 & 8.2 & 0.0 & 100 & Rata2 & 3.68 \\
\hline
\end{tabular}

Source: Self-processed primary data.

Table 17. Simple linear regression test results motivation variable (X1) against employee performance (Y)

\begin{tabular}{llrrrrrr}
\hline & & \multicolumn{2}{c}{ Unstandardized } & \multicolumn{3}{c}{$\begin{array}{c}\text { Standardized } \\
\text { Coefficients }\end{array}$} \\
& & B & Std. Error & Beta & & \\
& & 28.490 & 5.903 & & & 4.827 & .000 \\
\hline 1 & (Constant) & .581 & .101 & & .571 & 5.740 & .000 \\
\hline
\end{tabular}

Dependent Variable: Employee Performance (Y).

Table 18. Simple linear regression test results communication variable (X2) against employee performance $(\mathrm{Y})$

\begin{tabular}{llrrrrrr}
\hline & & \multicolumn{2}{c}{ Unstandardized } & \multicolumn{3}{c}{$\begin{array}{c}\text { Standardized } \\
\text { Coefficients }\end{array}$} \\
& Coefficients & B & Std. Error & Beta & & \\
\hline 1 & (Constant) & 27.148 & 6.685 & & & 4.061 & .000 \\
& Communication $(\mathrm{X} 2)$ & .574 & .109 & & .538 & 5.264 & .000 \\
\hline
\end{tabular}

Dependent Variable: Employee Performance (Y).

Table 19. Simple linear regression test results communication variable (X3)

\begin{tabular}{|c|c|c|c|c|c|c|}
\hline & & \multicolumn{2}{|c|}{$\begin{array}{c}\text { Unstandardized } \\
\text { Coefficients }\end{array}$} & \multirow{2}{*}{$\begin{array}{c}\text { Standardized } \\
\text { Coefficients } \\
\text { Beta }\end{array}$} & & \\
\hline & & B & Std. Error & & & \\
\hline 1 & (Constant) & 22.162 & 5.737 & & 3.863 & .000 \\
\hline & Work Discipline (X3) & .679 & .097 & .648 & 7.012 & .000 \\
\hline
\end{tabular}

Dependent Variable: Employee Performance (Y). 
Table 20. Results of multiple regression testing variables of motivation (X1), communication (X3) and work discipline (X3) against employee performance (Y)

\begin{tabular}{|c|c|c|c|c|c|c|}
\hline & \multicolumn{2}{|c|}{$\begin{array}{c}\text { Unstandardized } \\
\text { Coefficients }\end{array}$} & \multirow{2}{*}{$\begin{array}{c}\text { Standardized } \\
\text { Coefficients } \\
\text { Beta }\end{array}$} & & \\
\hline & & B & Std. Error & & & \\
\hline 1 & (Constant) & 1.172 & 6.581 & & -.178 & .000 \\
\hline & Motivation (X1) & .169 & .164 & .166 & 1.028 & .308 \\
\hline & Communication (X2) & .462 & .087 & .433 & 5.328 & .000 \\
\hline & Work Discipline (X3) & .432 & .172 & .412 & 2.512 & .014 \\
\hline
\end{tabular}

Dependent Variable: Employee Performance (Y).

Table 21. Correlations and coeeficient determination

\begin{tabular}{ccc}
\hline Variables & Correlations (R) & Coefficient Determinations (R2) \\
\hline Motivation & 0.571 & 0.326 \\
Communication & 0.538 & 0.290 \\
Work Discipline & 0.648 & 0.420 \\
Combination & 0.771 & 0.594 \\
\hline
\end{tabular}

Dependent Variable: Employee Performance (Y).

Table 21 shows the independent variables that have the lowest correlations and coefficient determinations are communication, motivation and work discipline and the combination has more explain than others. The correlations and coefficient determinations between motivation and employee performance are 0.571 and 0.326 consecutively; communication and employee performance are 0.538 and 0.290 ; work discipline and employee performance are 0.648 and 0.420 ; and among them are 0.771 and 0.594 .

\section{DISCUSSION}

The Effect of Motivation (X1) on Employee Performance ( $Y$ )

Based on the results of the analysis, the value of the regression equation $\mathrm{Y}=28.490+0.581 \mathrm{X} 1$, the correlation coefficient of 0.571 means that the two variables have a moderate relationship. Determination value or the influence contribution is 0.326 or $32.6 \%$. Hypothesis testing the value of $t$ arithmetic $>t$ table or $(5.740>1.995)$. It means that there is a significantly significant effect partial between motivation on employee performance at Alfa and Omega Company.

The Effect of Communication (X2) on Employee Performance (Y)
Based on the test results, the value of the regression equation $\mathrm{Y}=27,148+0,574 \mathrm{X} 2$, the correlation coefficient of 0,538 means that the two variables have a moderate level of relationship. The value of determination or contribution of influence is 0.290 or $29 \%$. Hypothesis test obtained value of $\mathrm{t}$ count $>\mathrm{t}$ table or $(5.264>$ 1.995). It is meaning that there is a partially significant effect between communication on employee performance at Alfa and Omega Company.

The Effect of Communication (X2) on Employee Performance (Y)

Based on the test results, the value of the regression equation $\mathrm{Y}=22.162+0.679 \mathrm{X} 3$, the correlation coefficient of 0.648 means that the two variables have a strong relationship level. The value of determination or contribution of influence is 0.420 or $42 \%$. Hypothesis test obtained value of $t$ count $>t$ table or $(7.012>$ 1.995). Thus, it is meaning that there is a partially significant influence between work discipline on employee performance at PT. Alpha and Omega.

The Influence of Motivation (X1), Communication (X2) and Work Discipline (X3) on Employee Performance (Y)

Based on the results of the study, it shows that 
motivation (X1), communication (X2) and work discipline (X3) have a positive effect on employee performance with the regression equation $\mathrm{Y}=$ $-1.172+0.169 \mathrm{X} 1+0.462 \mathrm{X} 2+0.432 \mathrm{X} 3$. The value of the correlation coefficient or the level of influence between the independent variable and the dependent variable was obtained at 0.771, which means that it has a strong relationship. The value of the coefficient of determination or contribution of influence simultaneously is $59.4 \%$. Hypothesis testing is obtained by the calculated $\mathrm{F}$ value $>$ Ftable or $(32.231>2.740)$. Thus HO is rejected and $\mathrm{H} 4$ is accepted. This means that there is a significant influence simultaneously between motivation, communication and work discipline on employee performance at PT. Alpha and Omega

\section{CONCLUSION}

All in all, motivation, communication, and work discipline have significant effects on employees' performance partially and simultaneously.with the regression equation $\mathrm{Y}=28.490+0.581 \mathrm{X} 1$, having a correlation coefficient of $32.6 \%$. Hypothesis test obtained $t$ count $>\mathrm{t}$ table or $(5.740>1.995)$ meaning that there is a significant influence between motivation on employee performance.

Communication has a significant effect on employee performance with the regression equation $\mathrm{Y}=27,148+0,574 \mathrm{X} 2$, has a correlation coefficient of $29 \%$. Hypothesis test obtained $\mathrm{t}$ count $>\mathrm{t}$ table or $(5.264>1.995)$ meaning that there is a significant influence between communication on employee performance.

Work discipline has a significant effect on employee performance with the regression equation $\mathrm{Y}=22.162+0.679 \mathrm{X} 3$, has a correlation coefficient of $42 \%$. Hypothesis test obtained $t$ count $>\mathrm{t}$ table or $(7.012>1.995)$ meaning that there is a significant influence between work discipline on employee performance.

Motivation, Communication and Work Discipline have a significant effect on Employee Performance with the regression equation $\mathrm{Y}=$ $-1.172+0.169 \mathrm{X} 1+0.462 \mathrm{X} 2+0.432 \mathrm{X} 3$. has a coefficient of determination relationship level of $59.4 \%$. Hypothesis test obtained value of $\mathrm{F}$ arithmetic $>\mathrm{F}$ table or $(32.231>2.740)$ meaning that there is a simultaneous significant influence between motivation, communication and work discipline on employee performance at Alpha and Omega Company.

\section{ACKNOWLEDGEMENT}

This research is self-funded

\section{REFERENCES}

Abid, M., \& Safiih, A. R. (2021). PENGARUH MOTIVASI KERJA TERHADAP KINERJA KARYAWAN PADA PT. PUTRA MULIA TELECOMMUNICATION SELAMA MEMBERLAKUKAN WFH (WROK FROM HOME). Jurnal Arastirma, 1(2), 216-225.

Asadullah, M. A., Ul Haq, M. Z., Wahba, K., Hashmi, S., Kim, H. (Markham), \& Hwang, J. (2021). Gender differences and employee performance: Evidence from the restaurant industry. Journal of Hospitality and Tourism Management, 48, 248-255. https://doi.org/ https://doi.org/10.1016/j.jhtm.2021.06.015.

Astria, K. (2018). Pengaruh Disiplin Kerja Dan Motivasi Terhadap Kinerja Karyawan Pada PT. Bank Rakyat Indonesia Cabang Pamulang. JURNAL MANDIRI: Ilmu Pengetahuan, Seni, Dan Teknologi, 2(1), 1-22.

Audenaert, M., Decramer, A., \& George, B. (2021). How to foster employee quality of life: The role of employee performance management and authentic leadership. Evaluation and Program Planning, 85, 101909. https://doi.org/https:// doi.org/10.1016/j.evalprogplan.2021.101909.

Barsah, A. (2019). PENGARUH KOMUNIASI ORGANISASI TERHADAP KINERJA KARYAWAN PADA PT. METROPOLITAN RETAILMART. Jurnal Ekonomi Efektif, 1(2).

Barsah, A., \& Ridwan, A. (2020). Pengaruh Etos Kerja dan Disiplin Kerja Terhadap Kinerja Karyawan Pada PT Pacific Indah Pratama Jakarta. Jurnal Madani: Ilmu Pengetahuan, Teknologi, Dan Humaniora, 3(1), 141-150.

Cay, S. (2018). PENGARUH KOMUNIKASI, MOTIVASI KERJA DAN STRES KERJA TERHADAP KINERJA GURU AL AZHAR 
BSD. KREATIF: Jurnal Ilmiah Prodi Manajemen Universitas Pamulang, 6(4), 3040.

Handayani, R. (2020). Pengaruh Disiplin Kerja dan Suasana Kerja Terhadap Kinerja Karyawan pada PT. Gunung Agung Tangerang Selatan. JENIUS (Jurnal Ilmiah Manajemen Sumber Daya Manusia), 3(2), 166-178.

Hasibuan. (2017). Manajemen Sumber Daya Manusia (Edisi Revisi). Bandung: Bumi Aksara.

Jie, H., Martínez, O. S., \& Crespo, R. G. (2020). The influence of employee emotional intelligence on enterprise innovation performance using an adaptive mathematical modeling of emotions. Aggression and Violent Behavior, 101538. https://doi.org/https://doi. org/10.1016/j.avb.2020.101538.

Khair, O. I. (2018). Pengaruh kepemimpinan, komunikasi organisasi, dan motivasi terhadap kinerja karyawan Grand manhattan club hotel borobudur Jakarta. Jurnal Madani: Ilmu Pengetahuan, Teknologi, Dan Humaniora, 1(1), 185-209.

Krisnaldy, K., Pasaribu, V. L. D., \& Batubara, A. S. (2020). Analisis Pengaruh Kedisiplinan Terhadap Performa Pegawai Kelurahan Rempoa, Kota Tangerang Selatan. Jurnal Mandiri: Ilmu Pengetahuan, Seni, Dan Teknologi, 4(2), 131-138.

Mangkunegara, A.A.A. (2015). Evaluasi Kinerja Sumber Daya Manusia. Cetakan keenam. Bandung: Rafika Aditama.

MOGI, A. (2020). PENGARUH KOMUNIKASI DAN DISIPLIN KERJA TERHADAP KINERJA KARYAWAN PADA PT. RAMAYANA LESTARI SENTOSA. TBK DI JAKARTA PUSAT. JURNAL SeMaRaK, 3(1), 75-84.

Mulyadi, M., \& Wicaksono, P. (2019). Pengaruh Motivasi Dan Budaya Organisasi Terhadap Kinerja Karyawan Pada PT. Fenixindo Global Mandiri (Veneta System). JENIUS (Jurnal Ilmiah Manajemen Sumber Daya Manusia), 3(1), 86-98.

Nazir, A. (2019). PENGARUH PELATIHAN DAN DISIPLIN KERJA TERHADAP
KINERJA KARYAWAN PADA PT SURYA MASTIKA NUSANTARA. Jurnal Mandiri: Ilmu Pengetahuan, Seni, Dan Teknologi, 3(1), 150-169.

Nurdina, A. (2018). PENGARUH BUDAYA ORGANISASI DAN MOTIVASI KERJA TERHADAP KINERJA KARYAWAN PADA BANK MANDIRI CLUSTER PAMULANG. KREATIF: Jurnal Ilmiah Prodi Manajemen Universitas Pamulang, 6(4), 1-12.

Oktavianti, N. (2020). Pengaruh Motivasi dan Kepuasan Kerja terhadap Kinerja Kerja Karyawan PT. DEW Indonesia. JENIUS (Jurnal Ilmiah Manajemen Sumber Daya Manusia), 3(2), 148-155.

Pratama, A. (2020). Pengaruh Kompensasi Dan Disiplin Kerja Terhadap Kinerja Karyawan Pada PT Pos Indonesia DC Ciputat. Jurnal Disrupsi Bisnis, 3(2), 146-158.

Rahmi, H. (2020). PENGARUH STRES KERJA DAN DISIPLIN KERJA TERHADAP KINERJA KARYAWAN PT NAWAKARA ARTA KENCANA FATMAWATI JAKARTA SELATAN. KREATIF: Jurnal Ilmiah Prodi Manajemen Universitas Pamulang, 8(1), 77-90.

Santoso, A. B. (2017). Pengaruh Disiplin Kerja, Motivasi, dan Komitmen Organisasi Terhadap Kinerja Karyawan (Pada PT. Bank Negara Indonesia (Persero) Cabang Pamulang). Jurnal Mandiri: Ilmu Pengetahuan, Seni, Dan Teknologi, 1(2), 247-272.

Senen, S. (2021). Pengaruh Rotasi Kerja, Komunikasi Organisasi, dan Kepuasan Kerja Terhadap Kinerja Karyawan di Kopegtel Jaya. Jurnal Madani: Ilmu Pengetahuan, Teknologi, Dan Humaniora, 4(1), 45-50.

Siagian, S. P. (2017). Manajemen Sumberdaya Manusia. Bandung: Bumi Aksara.

Sugiyono. (2018). Metode Penelitian Kuantitatif, Kualitatif dan R\&D. Bandung: Penerbit Alfabeta. Susanti, F. S. (2019). Pengaruh Pelatihan Dan Komunikasi Terhadap Kinerja Karyawan Pada Klinik Tumbuh Kembang Yamet Pamulang. Jurnal Semarak, 1(3), 39-48.

Sutardji. (2016). Perencanaan Dan Pengembangan Sumber Daya Manusia Edisi Pertama. Yogyakarta: Dese Publish. 
Suwatno, \& Priansa, D.J. (2016). Manajemen Sumber Daya Manusia Edisi Reguler. Bandung : Alfabeta.

Tohirin, T. (2018). PENGARUH SUPERVISI
DAN DAN DISIPLIN KERJA TERHADAP KINERJA GURU. Jurnal Mandiri: Ilmu Pengetahuan, Seni, Dan Teknologi, 2(1), 227 244. 